\title{
Developing Students' Critical Thinking Skills by Task-Based Learning in Chemistry Experiment Teaching
}

\author{
Qing Zhou ${ }^{1 *}$, Qiuyan Huang ${ }^{2}$, Hong Tian ${ }^{3}$ \\ ${ }^{1}$ Key Laboratory of Modern Teaching Technology, Ministry of Education of China and Shaanxi \\ Normal University, Xi'an, China \\ ${ }^{2}$ School of Chemistry \& Chemical Engineering, Shaanxi Normal University, Xi'an, China \\ ${ }^{3}$ Lanzhou Petrochemical College of Vocational Technology, Lanzhou, China \\ Email: zhouq@snnu.edu.cn
}

Received August 27 $7^{\text {th }}, 2103$; revised September $27^{\text {th }}, 2013$; accepted October $4^{\text {th }}, 2013$

\begin{abstract}
Copyright (C) 2013 Qing Zhou et al. This is an open access article distributed under the Creative Commons Attribution License, which permits unrestricted use, distribution, and reproduction in any medium, provided the original work is properly cited. In accordance of the Creative Commons Attribution License all Copyrights $\mathbb{C}$ 2013 are reserved for SCIRP and the owner of the intellectual property Qing Zhou et al. All Copyright (C 2013 are guarded by law and by SCIRP as a guardian.
\end{abstract}

Task-Based Learning (TBL) is a student-centered, teacher-guided and task-performed teaching approach. This study was aimed to investigate the effects of task-based learning (TBL) in chemistry experiment teaching on promoting high school students' critical thinking skills in Xi'an, China. To achieve the aims, a pre-test and post-test experimental design with an experimental group and a control group was employed. Students in the experimental group were taught with TBL, while students in the control group were taught with lecturing teaching methods. Five chemical experiments were selected, and 119 students aged at $17-19$ voluntarily participated in the research which lasted one semester. The California Critical Thinking Skills Test (CCTST) was used as a data collection tool. Results showed there was an obvious significant difference $(\mathrm{p}<0.05)$ in the dimension of analyticity in the experimental group after TBL, while there were no significant differences in the total score, the evaluation and inference of CCTST. The findings provide an effective way for chemistry teachers to improve students' critical thinking analyticity skills.

Keywords: Critical Thinking Skill; Task-Based Learning; Chemistry Experiment Teaching

\section{Introduction}

It is generally accepted that critical thinking should be an important dimension of science education (Bailin, 2002). Critical Thinking (CT) should be not only educational choice, but rather an inseparable part of education. Since the world has changed quickly, it demands that education should develop students' critical thinking at all levels rather than teaching obsolete knowledge. The Australian Curriculum Science (2012) has one of its aims which develop students' an understanding of the nature of scientific inquiry and the ability to use scientific inquiry methods. So many items focusing on the critical thinking are included, for example "they develop critical and creative thinking skills and challenge themselves to identity questions and draw evidence-based conclusions using scientific methods." (p. 3); "critical and creative thinking are integral to activeties that require students to think broadly and deeply using skills, behaviors and dispositions such as reason, logic, resourcefulness, imagination and innovation in all learning areas at school and in their lives beyond school." (p. 13); "In the science learning area, critical and creative thinking are embedded in the skills of posing questions, making predictions, speculating, solving problems through investigation, making evidencebased decisions, and analyzing and evaluating evidence." (p.

\footnotetext{
${ }^{*}$ Corresponding author.
}

13). Besides, there are also other curriculum statement and stands which focus on critical thinking from a wide range of jurisdiction, including the Ministry of Education, Singapore (2007); the National Academy of science, USA (1996); the department for education, England (1999).

\section{Definition of Critical Thinking}

Although CT is an important cognitive skill that schools aim to train up, there are differences of opinions existing in defining it. CT is a rich concept which has been developing for 2500 years. The intellectual root of CT originated in the method of questioning proposed by Socrates who established the importance of asking deep questions that probe profoundly into thinking before we accepted ideas as worthy of belief. Since then, different people studied the concept in different views of cognitive development, which led to the diversity of the conceptions (e.g., Brell, 1990; McPeck, 1981; Norris, 1985; Rogers, 1990; Seigel, 1988; Siegel \& Carey, 1989). The most widely used definition made by Ennis (1991) is that "reasonable reflective thinking focused on deciding what to believe or do" (p. 6). According to the definition, CT was an important component of the process of problem solving. Ennis (1991) divided critical thinking into critical thinking abilities and critical thinking disposition, but it was still lack of assessment criteria. The Ame- 
rican Philosophical Association (APA) sponsored a two-year Delphi research project which was included 46 persons active in critical thinking research, education, and assessment, and they conceptualized the critical thinking and constructed objectively scored standardized instruments the California Critical Thinking Skills Test (CCTST) and the California Critical Thinking Disposition Inventory (CCTDI). The panel's conceptualization of the critical thinking construct was summarized by Facione (1990):

We understand critical thinking to be purposeful, self-regulatory judgment which results in interpretation, analysis, evaluation, and inference, as well as explanation of the evidential, conceptual, methodological, criteriological, or contextual considerations upon which that judgment is based.

A good critical thinking includes both a skill dimension (Critical Thinking Skills, CTS) and a disposition dimension (Critical Thinking Disposition, CTD). CTS include 1) interpretation, 2) analysis, 3) evaluation, 4) inference, 5) explanation and 6) self-regulation. Interpretation is to categorize the problem, to define its characteristic, to decode and to clarify the meaning. Analysis is to distinguish the relationship among things. Evaluation is to make judgments on the credibility of statements. Inference is to reason and to make logical conclusions. Explanation is to state results, to justify procedures and to present arguments. Self-regulation is to reflect, to make self-assessment on one's cognitive activities and to correct the errors.

CTD contain 1) truth-seeking; 2) inquisitiveness; 3) ma- turity; 4) analyticity; 5) open-mindedness; 6) systematicity and 7) self-confidence (Margaret \& Colucciello, 1997). Truth-seeking is to be eager for exploring the knowledge even when the knowledge does not support one's self-interests or one's preconceived viewpoints. Inquisitiveness is to be inquisitive to obtain knowledge even when the knowledge is not used immediately. Maturity is cautious to make, to suspect and to revise decisions. Analyticity is to apply reasoning into solving problems and tend to expect the results. Open-mindedness is to be tolerant of diverse views. Systematicity is to be organized orderly, focused and engaged in handling the problems. Selfconfidence is to believe in one's own inference and tend to use the skills to solve problems.

CT is the human nature, but it's not natural for humans to think well. Being a critical thinker refers to obtain the critical thinking skills and the readiness, willingness and inclination to apply those skills. CTS are essential to any educated individual, and it's particularly necessary that they could be used and developed by students. There is consensus about the importance of CT, but differences of opinions exist in how CT should be taught. Some (Brookfield, 1987) insisted that there was no standard approach to facilitate critical thinking, while others (Barrows, 1986) advocated the use of specific strategies. Chemistry, a subject where critical thinking is applied in various ways, plays an important role in fostering students' CT. So there are many approaches to improve students' critical thinking (e.g. Charen, 1970; Seymour, 1973; Zhou et al., 2010a; Zhou, Guo, \& Wang, 2010b; Zhou, Shen, \& Tian, 2010c; Zhou et al., 2012; Evren, Bati, \& Yilmaz, 2012). For the literature mentioned above, most of the researches have focused on the influence that teaching methods had on critical thinking. For example, in Zhou's study $(2010 a, 2010 b)$ the inquiry-based chemical experiment was used to develop pre-service teachers' critical thinking. The CCTST and CCTDI were used to assess the pre-service teachers' critical thinking skills and disposition.
The results indicated that the implementation of the chemical inquiry experiments improved the analysis and evaluation in CTS and the analyticity in CTD significantly $(p<0.05)$, but other dimension of the two subscales did not show significant difference. Besides, in Zhou's study (2012) the WebQuest teaching method was applied to improving the high school students' critical thinking. There were significant differences ( $p$ $<0.05$ ) between before and after WebQuest learning in the CCTDI scores and the subscale scores of truth-seeking, inquisitiveness, analyticity, systematicity and self-confidence. For the CCTST, there were significant differences in the total score, and the subscales scores of analysis and evaluation. The findings indicated the WebQuest teaching in chemistry might be an effective method to develop high school students' critical thinking.

\section{Task-Based Learning in Chemistry Experiment Teaching}

Problem-Based Learning (PBL) is defined as the studentcentered and self-directed pedagogical approach (Barrows, 1996; Kek \& Huijser, 2011). PBL requires that the learning is done a small group which consists of 6 - 10 persons ideally. Problems form the basis of the learning focus on and simulate the students' cognitive development. Task-based learning (TBL) is also the learner-centered teaching methods. Student-centered leaning is that the students must take responsibility for their own learning, identify what they need to know, manage the problem on which they are working and determine where they will get that information, and the teacher is as the facilitators or guides (Barrows, 1996). The previous studies had shown the PBL was a powerful pedagogical approach to promote CT (e.g. Joe \& Elizabeth, 1999; Magnusseen, Ishida, \& Itano, 2000; Celia \& Gordon, 2001; Cook \& Moyle, 2002; Williams, 2002; Yuan \& Qian, 2003; Wang, Lu, \& Ze, 2004; Choi, 2004; Tiwari, Lai, So, \& Yeun, 2006; Wang, Tsai, Chiang, Lai, \& Lin, 2008; Yuan, Williams, \& Fan, 2008; Ozturk, Muslub, \& Diclea, 2008; Kek \& Huijser, 2011; Martyn, Terwijn, Kek, \& Huijser, in press; Choi, Lindquist, \& Song, in press). For the CTD, PBL promoted the senior nursing students' truth-seeking and openmindedness (Tiwari et al., 2006; Ozturk et al., 2008). And PBL influenced the students' CTS (Williams, 2002; Martyn et al., in press; Choi et al., in press). Since CT is an outcome of PBL (Worrell \& McGrath, 2007), we supposed that TBL also could improve the students' CT.

TBL was mainly applied in medical education (Harden, Crosby, Davis, \& Struthers, 2000; Ozan, Karademir, Gursel, Tanskiran \& Musal, 2005), language learning (Gass, Mackey, \& Feldman, 2011; Hashemi, Azizinezhad, \& Darvishi, 2012) and computer-aid learning (Whittington \& Campbell, 1998; Lee $\&$ Shin, 2012). But there were few about the TBL applied in chemistry experiment teaching (Zhou et al., 2010c). In the chemistry experiment teaching, TBL is more suitable than PBL, because TBL makes it possible for small group learning to take place without mobilizing tutors, while PBL needs the guide of instructors, especially in China where a class has about 50 students on average or even more, the teacher may feel exhausted and tired when they are guiding the chemistry experiment. The task is like the driving force that makes learning occurs proactively. By working towards task realization, the current knowledge and resource are used immediately by students, making learning initiatively and exploring independently. This is can be 
explained by social constructivism. Social constructivism theory emphasizes the critical importance of culture and the social context for cognitive development. Knowledge is constructed through collaboration-interactions among students and between students and teachers, connected by task in TBL (Atwater, 1996). The learning results are not only the tasks but also the concepts and mechanisms underlying the tasks (Harden et al., 2000). Moreover, the cooperation in students is utilized fully and the team spirit is fostered through TBL. So TBL is a good choice for teachers in the chemistry experiment teaching.

TBL has been applied in high school chemistry experiment teaching and has been tested the effect of critical thinking disposition in Zhou's research (2010c). The result showed there were significant differences on the CCTDI total score and the subscale score of self-confidence between the experimental group and the control group in the posttest. There is the evidence that critical thinking disposition correlates with critical thinking skills (Facione \& Facione, 1997). Since the TBL is an effective method for developing students' critical thinking disposition, the hypotheses of this study the students' CT skills can be developed and fostered by TBL. So the focus of this paper still examines whether the TBL influences on the students' critical thinking skills in high school.

\section{Methodology}

\section{Research Design}

To achieve the aims, a pre-test and post-test experimental design with an experimental group and a control group was employed. Students in the experimental group were taught with TBL, while students in the control group were taught with traditional teaching methods in the experiments. Five chemical experiments were chosen as the main instructional materials because they represented that the chemistry knowledge applied in real life, which were "Reaction between sodium peroxide and water", "Esterification", "Alum for water purification", "Preparation of silicic acid" and "Preparation of ferrous hydroxide". The experiment lasted one semester. The California Critical Thinking Skills Test (CCTST) was used as the data collecting tool. At the beginning of the semester, the CCTST was conducted in the control group and the experimental group to assess their CT skills level and examine whether there were differences. At the end of the semester, the CCTST was also implemented in the two groups to make a comparison with the pre-test and test the hypotheses.

\section{Participants}

The selected sample in this study was 119 students whose ages ranged from 17 to 19 years at grade 3 in YuJin Middle School, Xi'an, Shaanxi Province, China. There were 59 students in the experimental group which were taught by TBL, and 60 students in the control group which were taught with the lecturing teaching method.

\section{Procedures}

In order to guarantee the results were objective and authentic, several treatments were conducted. First of all, an introduction about the concept of CT to all the participants was made before the experiment to ensure that they were able to use it. Secondly, before the experiment the students who had similar learning level were selected in the two groups. Finally, all the participants were taught by the same teacher who used the same teaching content to reduce the effect of the non-research variables (e.g. the teaching style, the teaching standard), and the course goals were the same for both the experimental group and the control group. The differences lay in the teaching method that the teacher used. In the control group, the teacher gave a lecture directly to the students about the chemistry experiment which included the experiment principle, instruments and procedures and so on. The lecture is defined as of more or less uninterrupted talk from the teacher. Lecture notes were provided for the students for each of the experiment. Then the students did the experiments according to the procedures in the notes.

In the experimental group, the teacher used the TBL to help the students construct the knowledge. Take the topic "Reaction between sodium peroxide and water" for example to illustrate the TBL teaching.

Firstly, the teacher presented the task background and assigned the task. The products of the reaction between sodium peroxide and water were sodium hydroxide and oxygen. After the reaction phenolphthalein was dropped into the solution, it showed red for some period of time, which was the normal phenomenon because phenolphthalein became red in the sodium hydroxide solution. However, the eight to ten drops of phenolphthalein was dropped into the solution, and it appeared red. But when the tube was oscillated, the red color disappeared. It seemed strange. So the task was inquiry on the fading reason of the reaction between sodium peroxide and water.

Secondly, the students were divided into small groups with a unit of six persons, based on their interests, ability and desire. Secondly, according to the teaching target and content, each student in a group was given different role to complete the task. There were mainly six roles: 1) Planner, who organized the group members, made a schedule and supervised the implementation; 2) Information collector, who assigned the collecting materials task to the members and gathered the information in chief, such as the physical properties, the chemical properties and the use of sodium peroxide; 3) Data organizer, who arranged the information systematically; 4) Scheme designer, who make the designing scheme exploring the fading phenomena of the reaction between sodium peroxide and water; 5) Experiment preparation, who prepared the experimental drugs and equipments according to the scheme; 6) Presenter, who displayed the experiment scheme based on the group member argument.

Thirdly, after the division of labor, each group member defined his /her role and task depended on the fact. A fixed group leader was not set, and each member served as the leader by turns.

Before the experiment, 5 minutes were given to each group to present the reason analyses on the fading phenomena and the corresponding experiment scheme.

And the teacher evaluated the scheme, discussed with the classmates, and produced the optimum solution. Under the teacher's guidance and supervision, the students did the experiment. After completing the experiment, the students communicated with each other on the things they had gained in the process. Besides, the teacher evaluated and summed up the knowledge and skills. TBL required the teacher make the timely evaluation to stimulate the students' interests and motivation. There were four methods which were the self-evaluation, in- 
tra-group evaluation, inter-evaluation among groups, and teacher-evaluation. Self-evaluation could develop the students' independent consciousness. Students learn to appreciate other people and make judgment through intra-group evaluation and inter-evaluation among groups. And teacher could point out the problem existing in process.

\section{Instrument}

The framework of CCTST is based on the APA Delphi consensus conceptualization of critical thinking (1990) and developed by Facione (1994). It is a 34-item standardized multiple-choice test and is aimed at college students and adults, but also suitable for advanced and gifted high school students. The skills of analysis, evaluation and inference, deductive reasoning and inductive reasoning are specifically targeted by the CCTST. The Inductive and deductive scales overlap with the analysis, inference, and evaluation scales. Analysis, inference, and evaluation add up to the CCTST total score. Induction and deduction also add up to the CCTST total score. The deductive reasoning and inductive reasoning were integrated into the three subscales of the analysis (A) $(0-9)$, evaluation (E) $(0-14)$ and inference (Inf) $(0$ - 11) in the Chinese-version CCTST (2002), which produces an yields an overall score $(0-34)$ on critical thinking skills, Pearson $r=0.63, p<0.01, r / 2=(0.75-0.80), p$ $<0.01$, and shows a good reliability, and good construct validity.

\section{Data Analysis}

The data were analyzed using the SPSS17.0 for windows versions. Independent sample t-test analysis and paired sample t-test were employed to compare CCTST scores before and after TBL.

\section{Results and Discussion}

Two methods were employed to compare the differences in the statistics. The first method was used the independent sample t-test (see Table 1). As shown in Table 1, the overall mean score of the critical thinking skills in the experimental group was $10.05 \pm 2.66$ in the pre-test and $10.58 \pm 2.76$ in the posttest, and the score in the control group was $10.65 \pm 2.67$ in the pre-test and $10.05 \pm 2.80$ in the post-test. But the overall mean score of the post-test was higher than the pre-test in the ex- perimental group, while the score of the post-test was lower than the pre-test in the control group. No significant difference was found in the overall score. Compared the subscales scores in the two groups, the experimental group's score was lower than the control group's score in the pre-test, but in the post-test the control group's score was lower than the experimental group's. There were no statistically significant differences in the subscales of the two groups. The relationship of three skills' scores on the CCTST no matter in pre- or post-test or in the two groups the sequences are $\mathrm{E}>\mathrm{A}>\mathrm{Inf}$ (Analysis, Evaluation, Inference).

The second method was used the paired-sample t-test (see Table 2). Despite the overall score growth in the post-test, from 10.05 to 10.58 , the score in the post-test was not significantly different from those in the pre-test. The mean score of analysis in the experimental group is 3.49 in the pre-test and it is 3.96 in the post-test, increasing by 0.47 point $(\mathrm{t}=2.065$, $\mathrm{p}<0.05)$, which showed significant difference. The consequence indicated that TBL could develop students' analysis skills in chemistry experiment teaching. The other two subscales Evaluation and Inference have no statistically significant differences in the two tests. Figure 1 also demonstrated the change of the critical thinking skills subscales in the experimental groups in the preand post-test, and there was an increasing in the analysis and almost no change in the evaluation and inference, which proved the students' analysis skills, can be improved by TBL in chemistry experiment teaching.

\section{Discussion}

The above results showed that there was a significant difference of subscale analysis score in the experiment group in the pretest and posttest $(\mathrm{p}<0.05)$. It indicated that the students' analysis skills level could be improved by the TBL in chemistry experiment, though it had little impact on the other two skills evaluation and inference. In CCTST, analysis has two meanings. On the one hand, it means categorization, decoding sentence and clarifying meaning. On the other hand, it means examining ideas, identifying arguments and analyzing arguments (Facione, 1990). A good teaching method is the one that implies relevant and visible training values which shall motivate students and make them aware of their understanding and reflection, help them make up their critical thinking which will guarantee their trust in their own forces (Iurea et al., 2011) TBL is a good tea-

Table 1.

Comparison of pre- and post-test on CCTST in the experimental group and control group (independent sample t-test).

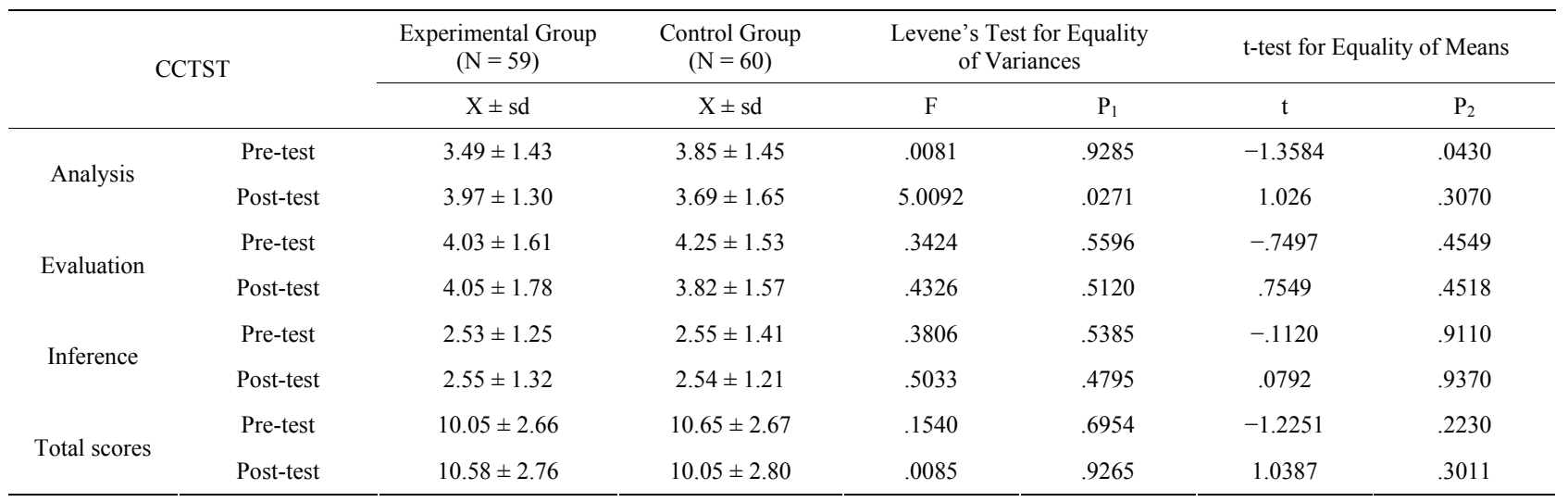


Table 2.

Comparison of pre- and post-test on CCTST in the experimental group (paired sample t-test).

\begin{tabular}{cccccc}
\hline \multirow{2}{*}{ CCTST } & Pre-test $(\mathrm{N}=59)$ & Post-test $(\mathrm{N}=59)$ & \multirow{2}{*}{$\mathrm{t}$} & $\mathrm{P}_{2}$ \\
\cline { 2 - 3 } & $\mathrm{X} \pm \mathrm{sd}$ & $\mathrm{X} \pm \mathrm{sd}$ & & \\
\hline Analysis & $3.49 \pm 1.43$ & $3.96 \pm 1.3$ & $2.065^{*}$ & .043 \\
Evaluation & $4.03 \pm 1.61$ & $4.05 \pm 1.78$ & .056 & .956 \\
Inference & $2.53 \pm 1.25$ & $2.56 \pm 1.32$ & .154 & .878 \\
Total score & $10.05 \pm 2.66$ & $10.58 \pm 2.76$ & 1.17 & .247 \\
${ }^{*} \mathrm{p}<0.05$. & & & &
\end{tabular}

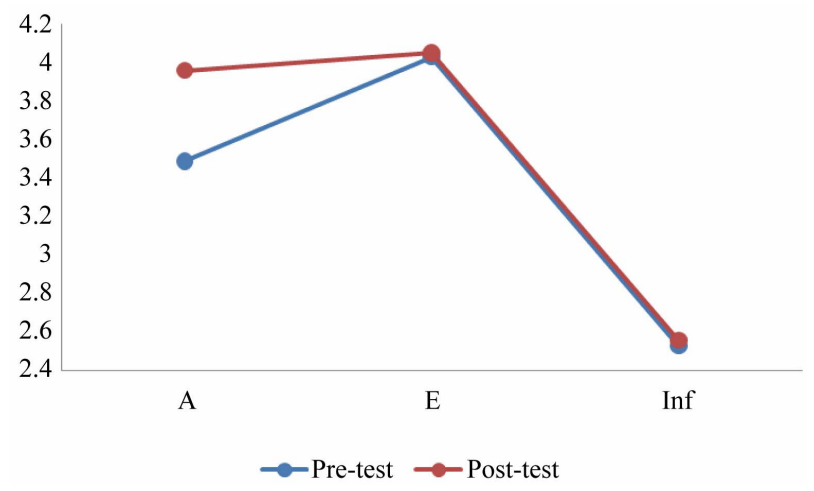

Figure 1.

Mean scores of CCTST three subscales of experimental group for two tests. Note: $\mathrm{A}=$ analysis; $\mathrm{E}=$ evaluation; $\mathrm{Inf}=$ inference.

ching method and an active learning approach that provides students with real-world situations and a chance to exercise their critical thinking skills. At the same time, teamwork environment inspires students to collaborate with teammates and to cultivate their team spirit and leadership.

\section{Conclusion}

As Martin Luther King said, "The function of education is to teach one to think intensively and to think critically". This study showed that TBL has revealed the advantage of fostering the students' critical thinking. The total score and the analysis score were higher than the control groups. However, some limitations of this study must be acknowledged. The level of evaluation and inference has not changed much in the experiment group in the posttest. It could be explained by the fact that the time-span covered by the experiments in class may have been too short to allow the effects of the new method to be integrated. Besides, the research and methods on developing and cultivating students' critical thinking are still needed.

\section{Acknowledgements}

Qiuyan Huang gratefully thanks for the support of Innovation Funds of Graduate Programs, provided by Shaanxi Normal University.

\section{REFERENCES}

Atwater, M. M. (1996). Social Constructivism: Infusion into the multicultural science education research agenda. Journal of Research in
Science Teaching, 33, 821-837.

http://dx.doi.org/10.1002/(SICI)1098-2736(199610)33:8<821::AIDTEA1>3.0.CO;2-Y

Australian Curriculum, Assessment and Reporting Authority. (2012). The Australian curriculum science (version 3.0).

http://www.australiancurriculum.edu.au/Science/Rationale

Bailin, S. (2002). Critical thinking and science education. Science \& Education, 11, 361-375. http://dx.doi.org/10.1023/A:1016042608621

Barrows, H. S. (1986). A taxonomy of problem-based learning methods. Medical Education, 20, 481-486. http://dx.doi.org/10.1111/j.1365-2923.1986.tb01386.x

Barrows, H. S. (1996). Problem-based learning in medicine and beyond: A brief overview. New Directions for Teaching and Learning, 68, 312. http://dx.doi.org/10.1002/tl.37219966804

Brell, C. D. (1990). Critical thinking as transfer: The reconstructive integration of otherwise discrete interpretations of experience. Educational Theory, 40, 53-68. http://dx.doi.org/10.1111/j.1741-5446.1990.00053.x

Brookfield, S. (1987). Developing critical thinkers: Challenging adults to explore alternative ways of thinking and acting. ST. Paul, IL: Open University Press.

Celia, L. M., \& Gordon, P. R. (2001). Using problem-based learning to promote critical thinking in an orientation program for novice nurses. Journal Nurses Staff Development, 17, 12-17. http://dx.doi.org/10.1097/00124645-200101000-00002

Charen, G. (1970). Do laboratory methods stimulate critical thinking? Science Education, 54, 267-271. http://dx.doi.org/10.1002/sce.3730540315

Choi, H. (2004). The effects of problem-based learning on the metacognition, critical thinking, and problem solving process of nursing students. Taehan KAnho Hakhoe Chi, 34, 712-721.

Choi, E., Lindquist, R., \& Song. Y. (in Press). Effects of problem-based learning vs. traditional lecture on Korean nursing students' critical thinking, problem-solving, and self-directed learning. Nurse Education Today. http://dx.doi.org/10.1016/j.nedt.2013.02.012

Clark, J., Scarino, A., \& Brownell, J. (1994). Improving the quality of learning: A framework for target-oriented curriculum renewal. Hong Kong: Institute of Language in Education,

Cook, M., \& Moyle, K. (2002). Students' evaluation of problem-based learning. Nurse Education Today, 22, 330-339. http://dx.doi.org/10.1054/nedt.2001.0713

Curriculum Planning \& Development Division. (2007). Science syllabus lower secondary express/normal (academic). http://www.moe.gov.sg/education/syllabuses/sciences/files/science-1 ower-secondary-2008.pdf

Department for Education. (1999). The national curriculum for England science. London: Depended for Education and Employment \& Qualifications and Curriculum Authority.

Evren, A., Bati, K., \& Yilmaz, S. (2012). The effect of using v-diagrams in science and technology laboratory teaching on preservice teachers' critical thinking disposition. Procedia Social and Behavioral Sciences, 46, 2267-2272.

http://dx.doi.org/10.1016/j.sbspro.2012.05.467

Ennis, R. (1991). Critical thinking: A streamlined conception. Teaching Philosophy, 14, 15-24. http://dx.doi.org/10.5840/teachphil19911412

Facione, N. C., \& Facione, P. A. (1997) Critical thinking assessment in nursing education programs: An aggregate data analysis. Millbrae, California, IL: California Academic Press.

Facione, P. A. (1990). Critical thinking: A statement of expert consensus for purposes of educational assessment and instruction. Millbrae, California, IL: California Academic Press.

Facione, P. A., \& Facione, N. C. (1994). The california critical thinking skills test: Test manual. Millbrae, California. IL: California Academic Press

Gass, S., Mackey, A., \& Feldman, L. R. (2011). Task-Based Interactions in Classroom and Laboratory Settings. Language learning, 61, $189-220$. 
http://dx.doi.org/10.1111/j.1467-9922.2011.00646.x

Harden, R. M., Crosby, J., Davis, M. H., \& Struthers, A. D. (2000). Task-based learning: The answer to integration and problem-based learning in the clinical years. Medical Education, 34, 391-397. http://dx.doi.org/10.1046/j.1365-2923.2000.00698.x

Hashemi, M., Azizinezhad, M., \& Darvishi. S. (2012). Using taskbased language teaching, learning practically in English classes. Procedia Social and Behavioral Sciences, 31, 526-529. http://dx.doi.org/10.1016/j.sbspro.2011.12.098

Iurea, C., Neacşu, I., Safta, C. G., \& Suditu, M. (2011). The study of the relation between the teaching methods and the learning styles - The impact upon the students' academic conduct. Procedia Social and Behavioral Sciences, 11, 256-260. http://dx.doi.org/10.1016/j.sbspro.2011.01.072

Joe, W. M., \& Elizabeth, A. (1999). Problem-based learning: An outcomes study. Nurse Education, 24, 33-36. http://dx.doi.org/10.1097/00006223-199903000-00011

Kek, M. Y. C. A., \& Huijser, H. (2011). The power of problem-based learning in developing critical thinking skills: Preparing students for tomorrow's digital futures in today's classrooms. Higher Education Research \& Development, 30, 317-329.

http://dx.doi.org/10.1080/07294360.2010.501074

Lee, D. Y., \& Shin, D. H. (2012) An empirical evaluation of multi-media based learning of a procedural task. Computers in Human Behavior, 28, 1072-1081.

http://dx.doi.org/10.1016/j.chb.2012.01.014

Magnusseen, L., Ishida, D., \& Itano, J. (2000). The impact of the use of inquiry-based learning as a teaching methodology on the development of critical thinking. Journal of Nursing Education, 39, 360-364.

Martyn, J., Terwijn, R., Kek, M. Y. C. A., \& Huijser, H. (in press). Exploring the relationships between teaching, approaches to learning and critical thinking in a problem-based learning foundation nursing course. Nurse Education Today.

http://dx.doi.org/10.1016/j.nedt.2013.04.023

Colucciello, M. L. (1997). Critical thinking skills and dispositions of baccalaureate nursing students: A conceptual model for evaluation. Journal of Professional Nursing, 13, 236-245.

http://dx.doi.org/10.1016/S8755-7223(97)80094-4

McPeck, J. E. (1981). Critical thinking and education. New York: St. Martin's.

National Academy of Sciences. (1996). National science education standards. Washington DC., IL: National Academy Press,

Norris, S. P. (1985). The choice of standard conditions in defining criticism thinking competence. Educational Theory, 35, 97-107. http://dx.doi.org/10.1111/j.1741-5446.1985.00097.x

Ozan, S., Karademir, Y., Gursel, Tanskiran, H. C., \& Musal, B. (2005). First graduates' perceptions on a problem-based and task-based learning curriculum. Education for Health, 18, 256-271. http://dx.doi.org/10.1080/13576280500148007

Ozturk, C., Muslub, G. K., \& Diclea. A. (2008). A comparison of problem-based and traditional education on nursing students' critical thinking dispositions. Nurse Education Today, 28, 627-632. http://dx.doi.org/10.1016/j.nedt.2007.10.001

Rogers, P. (1990). Discovery, learning, critical thinking, and the nature of knowledge. British Journal of Educational Studies, 38, 13-14. http://dx.doi.org/10.1080/00071005.1990.9973831
Seigel, H. (1988). Educating reason: Rationality, critical thinking, and education. New York: Routledge.

Seymour, L. A. (1973). Critical thinking ability, open-mindedness, and knowledge of the processes of science of chemistry and non-chemistry students. Journal of Research in Science Teaching, 10, 159163. http://dx.doi.org/10.1002/tea.3660100209

Siegel, M., \& Carey, R. F. (1989). Critical thinking: A semiotic perspective. Bloomington, IN: ERIC Clearinghouse on Reading and Communication Skills.

Tiwari, A., Lai, P., So, M., \& Yeun, K. (2006). A comparison of the effects of problem-based learning and lecturing on the development of students' critical thinking. Medical Education, 40, 547-554. http://dx.doi.org/10.1111/j.1365-2929.2006.02481.X

Wang, S. Y., Tsai, J. C., Chiang, H. C., Lai, C. S., \& Lin, H. J. (2008). Socrates, problem-based learning and critical thinking-A philosophic point of view. The Kaohsiung Journal of Medical Sciences, 24, S6-S13. http://dx.doi.org/10.1016/S1607-551X(08)70088-3

Wang, X. L., Lu, X. R., \& Ze, Y. X. (2004). Applied study of the problem based learning methods for clinical nursing education. Journal Nursing Training (Chinese), 19, 968-970.

Whittington, D., \& Campbell, L. (1998). Task-based learning environments in a virtual university. Computer Networks and ISDN Systems, 30, 707-709. http://dx.doi.org/10.1016/S0169-7552(98)00037-3

Williams, B. (2002). Development of critical thinking through problembased learning: A pilot study. Journal on Excellening in College Teaching, 11, 203-226.

Willis, J. (1996). A framework for task-based learning. TESOL Quarterly, 33, 157-158.

Worrell, J. A., \& McGrath, J. P. (2007). Critical thinking as an outcome of context-based learning among post RN students: A literature review. Nurse Education Today, 27, 420-426. http://dx.doi.org/10.1016/j.nedt.2006.07.004

Yuan, H. B., \& Qian, X. L. (2003). Application of problem-based teaching method in nursing. Journal of Nursing Training (Chinese), 18, 148150.

Yuan, H. B., Williams, B. A., \& Fan, L. (2008). A systematic review of selected evidence on developing nursing students' critical thinking through problem-based learning. Nurse Education Today, 28, 657663. http://dx.doi.org/10.1016/j.nedt.2007.12.006

Zhou, Q., Guo J., Liu, Y. Z., Wang, T., \& Ma, J. P. (2010a). Promoting preservice teachers' critical thinking disposition by inquiry-based chemical experiment. Procedia Social and Behavioral Sciences, 9, 1429-1436. http://dx.doi.org/10.1016/j.sbspro.2010.12.345

Zhou, Q., Guo, J., \& Wang, Y. (2010b). Promoting preservice teachers' critical thinking skills by inquiry-based chemical experiment. Procedia Social and Behavioral Sciences, 2, 4597-4603. http://dx.doi.org/10.1016/j.sbspro.2010.03.737

Zhou, Q., Shen, N., \& Tian, H. (2010c). Developing critical thinking disposition by task-based learning in chemistry experiment teaching. Procedia Social and Behavioral Sciences, 2, 4561-4570. http://dx.doi.org/10.1016/j.sbspro.2010.03.731

Zhou, Q., Ma, L. L., Huang, N., Liang, Q., Yue, H. J., \& Peng, T. (2012). Integrating webquest into chemistry classroom teaching to promote students' critical thinking. Creative Education, 3, 369-374. http://dx.doi.org/10.4236/ce.2012.33058 